\title{
Recommended Practices for Improving the Competitiveness of the Russian Education Services Market under the Conditions of the International Educational Integration
}

\author{
Natalya I. Kovaleva ${ }^{1}$, Nailya Sh. Valeyeva ${ }^{2}$, Natalya L. Avilova ${ }^{3}$, Guzyal M. Kharisova ${ }^{4}$, Ramil R. \\ Khayrutdinov $^{5}$, Elmira R. Khairullina ${ }^{2} \&$ Albert K. Shaikhlislamov $^{5}$ \\ ${ }^{1}$ The Moscow State Institute of Tourism Industry named after Y. A. Senkevich, Moscow, Russia \\ ${ }^{2}$ Kazan National Research Technological University, Kazan, Russia \\ ${ }^{3}$ Russian State University of Tourism and Service, Moscow, Russia \\ ${ }^{4}$ Kazan State University of Architecture and Engineering, Kazan, Russia \\ ${ }^{5}$ Kazan (Volga region) Federal University, Kazan, Russia \\ Correspondence: Natalya I. Kovaleva, The Moscow State Institute of Tourism Industry named after Y. A. \\ Senkevich, Kronshtadsky Boulevard, 43-a, Moscow, 125499, Russia. E-mail: nata60iosif@list.ru
}

Received: December 29, $2014 \quad$ Accepted: January 22, $2015 \quad$ Online Published: February 11, 2015

doi:10.5539/res.v7n4p1 URL: http://dx.doi.org/10.5539/res.v7n4p1

\begin{abstract}
To achieve and maintain a level of training for competitive specialists who meet modern requirements first and foremost in professional education it requires ensuring the competitiveness of the Russian education services market. In the article the research and methodological practices are proposed for improving the competitiveness of the Russian education services market under the conditions of international educational integration at the federal (legal and regulatory, organizational and pedagogical, organizational and methodological program), regional (legal and regulatory, organizational and administrative, organizational and methodological, and socially-pedagogical program) and university levels (legal and regulatory, organizational and administrative, socially-pedagogical, learning and teaching, and information-technology program). The proposed recommendations in the article are of practical value for international departments of higher education institutions in order to optimize the processes of Russian universities entering into the international educational space.
\end{abstract}

Keywords: competitiveness, professional training, educational services, international educational integration

\section{Introduction}

Education is an important area of human activity that provides social progress, level of civilization and development of spiritual and cultural spheres. By the level of development and peculiarities of formation of the higher education system we can estimate the economic, moral and cultural development of the whole society.

The current stage of development of Russian society, associated with intense changes in the political, economic and sociocultural life due to the impact of market reforms, has a significant impact on the identification of emphasis and priorities in the education system development (Colin, 2002; Fedotov, 2003; Fayzullina, 2007; Levina et al., 2015; Merzon et al., 2015; Sakhieva et al., 2015).

Currently, the main directions for its development are connected with the change of pedagogical paradigms, update of education content, entry into the world educational space. Among the development trends of the latter the most important is the integration of educational systems, based on developing common approaches for compulsory transfer of experience, common values, which are mainly the values to the fore associated with the formation of the younger generation world outlook (Baydenko, 2009; Balakireva, 2009; Evreinov, 2002; Shaidullina \& Masalimova, 2006; Mrathuzina et al., 2015).

Striving of educational systems of certain countries and regions to convergence and cooperation has become an objective reality of today and, of course, needs a scientific understanding and analysis (Fayzullina \& Mukhametzyanova-Duggal, 2015). The issue on preconditions, regularities and prospects for integration trends 
in contemporary higher education goes far beyond the pedagogical science, becoming a major philosophical, socio-economic and psychological problem (Klimanovich, 2001; Lukichev, 2003; Masalimova, 2012).

Complexity and diversity of this phenomenon has brought to life a multitude of its studies and interpretations. This problem was investigated by both domestic and foreign scholars: Batyukova (2005), Yermolyeva (1994), Megrat (2001), Pelikhov, Rodionov (2009), Sadlak (2007) and Henvi (1994). Special research works by Liferov, Kolker (1995) and Stepanov (1997) should be also noted. In socially-pedagogical studies of the problem the basic laws of higher education development are revealed, the prerequisites of its integration tendencies formation are analyzed; possible prospects for international cooperation in the field of education are assessed (Huseynov, 2005; Avraamova, Aleksandrova, \& Loginov, 2004).

\section{Results}

Our suggested guidelines to improve the competitiveness of the Russian education services market under the conditions of international educational integration are summarized in the following levels.

\subsection{At the Federal Level}

- Legal and regulatory support: creation of a regulatory framework for implementing double degree programs, joint educational programs; development and implementation of international programs and projects in the field of education and research activities in the education system, definition of the legal status of joint international educational programs;

- Organizational and pedagogical support: defining the procedure for establishing the equivalence of documents not only on the appropriate education, but also on scientific degrees and academic titles obtained in foreign countries, and for issuing certificates on the equivalence of the specified documents (including the determination of a unified procedure for issuing the European Diploma Supplements and dealing with the problems of recognizing the European Diploma Supplements issued by foreign universities); ensuring the established procedure of foreign students enrollment (stateless persons) for education, internships and advanced training in the Russian Federation;

- Organizational and methodological support: creation of incentives for developing institutional maintaining of academic mobility in universities (including the academic mobility into the number of accreditation parameters with mandatory qualitative evaluation of results); formation of a system of staff training and retraining in the education area in the field of international cooperation management.

\subsection{At the Regional Level}

- Legal and regulatory support: development of cooperation between regional and foreign universities: creation of joint curriculums (double degree programs); creation and implementation of "external" programs of regional universities in Europe, Russia and other countries; exchange of students and teachers;

- Organizational and administrative support: networking cooperation of universities in different countries within the scope of research projects and projects aimed at developing common approaches and common understanding of the content of educational programs, learning outcomes, and competence requirements in the areas of training:

- Organizational and methodological support: joint development and implementation of innovative courses; holding of joint seminars, conferences, summer schools; joint implementation of research projects involving integration of the results into the educational process; creating together with foreign partners different structural units (research and methodology centers, laboratories, technology parks and other similar structural units); organization of methodological seminars and conferences; development of teaching materials, publications, support for thematic portals; organization of public discussions and dissemination of project results.

- Socially-pedagogical support: support for academic mobility of teachers (fellowships for advanced training; collection of materials for research or preparation of new programs; preparation for establishing joint curriculums; participation in seminars, conferences) and students, postgraduate students (grants, training throughout a semester under the condition of credit transfers for learning outcomes in the sending University; training throughout a year under the condition of credit transfers for learning outcomes in the sending University; participation in conferences and seminars) (Scott, 2000; Popov, 2002).

\subsection{At the University Level}

- Legal and regulatory support, which implies the implementation of double degree programs, joint educational programs, the adoption of a number of documents of regulatory and methodological framework, such as: 1) Regulation on the implementation of the long-term cooperative educational programs (with a sample of documents and guidelines for organizing long-term educational programs); 2) Regulation on the implementation 
of short-term joint educational programs (with a sample of documents and guidelines for organizing short-term educational programs); 3) The registration of a "European application" to diploma of a higher school graduate (with the sample, the translation procedure application for assessing the progress and the workload of courses) (Gitman, Gitman, \& Stolbova, 2006);

- Organizational and administrative support, presupposing: a need to create a brand of one's own institution, that is to carry out business, international, innovative activities of the university, image and business reputation of the university management, providing predictive (anticipatory) management, development of a model for managing motivation of higher school;

- Socially-pedagogical support: establishment of the institution of advisers on academic problems (tutors) to help students in solving problems related to training; expansion of the practice of developing international educational programs, including franchising and double degree programs; interaction with employers throughout the whole training cycle;

- Learning and teaching support: combining disciplines of the curriculum into modules taking into account their logical and temporal sequence; developing effective procedures for carrying out independent work; developing a set of handouts for foreign students who have difficulty in communicating in an international language;

- Information-technology support: formation of educational information package in accordance with the arrangements for international recognition (with the definition of goals, objectives and desired outcomes for each course, module and educational program as a whole in terms of competencies); establishment and description of a clear and transparent system of assessment and accounting of learning outcomes, including the requirements for the training level of a student; creation of a specialized permanent information network serving as an integrator and distributor of reliable and complete information for all subjects of the professional educational institution.

\subsection{Description of the Experiment}

These recommended practices are reflected in the specialized course of study "Competitiveness of professional education in the international educational integration", which was being implemented for teachers in Almetyevsk State Petroleum Institute.

During the experimental work we were introducing the course "Competitiveness of professional education in the international educational integration" for the faculty of the Almetyevsk State Petroleum Institute. The need for the development of this course was due to the fact that in the initial stage of the experiment back in 2009 the conducted surveys and interviews with teachers of Almetyevsk State Petroleum Institute showed that they had a lack of understanding the factors and conditions of competitive participation of Russian professional education in the international education market. Of these, only $24 \%$ of the respondents recognized the benefits of the international educational integration, however, the rest of the surveyed teachers expressed concerns about the fact that these processes can lead to a reduction of the fundamental component which affects the quality of training future professionals, to a loss of highly qualified teachers of graduating chairs - experts in specific fields of professional knowledge resulting from the reduction of the period of studies, to a loss of continuity of scientific schools, loss of the status of the Russian primary and secondary vocational education, to low competitiveness of specialists by reducing training time, to increasing the cost of individual training of Master students because of the low number of the best Bachelor graduates able to go into further study, for a Master's, as well as to emergence of problems with bachelors' employment. $38 \%$ of teachers indicated in the surveys the unavailability of the higher school for joining the Bologna process and its transitioning to modular training. However, all the respondents agree that international educational integration can lead to recognition of diplomas of Russian universities by employers in other countries, to possibility of maintaining contacts with various international communities, to enhancing social and academic mobility, to opportunities for continuing education at any university.

After having been introduced to the specialized course of study "Competitiveness of professional education in the international educational integration" in April 2011, the teachers of Almetyevsk State Petroleum Institute were retested, and the statistical analysis of the test results let us conclude that the percentage ratio of the teachers' positive responses had increased, which indeed showed evidence for their readiness to participate in the international educational integration, and, accordingly, confirmed the practical significance of the developed specialized course of study.

\section{Discussions}

Integration in education, as opposed to internationalization, is characterized by stability of relations of national 
educational systems, by certain possibilities of planning and regulating these relations with the help of specially created institutionally-legal environment. In this case, the inseparable connections are guaranteed by the fact that the occurring phenomena of disintegration in the emerging educational space encounter the created political, sociocultural, legal and economic barriers preventing reverse movement.

The main actors of the integration are educational institutions of various levels, which, through mass inclusion in the implementation of major multilateral international projects and programs, more effectively begin addressing both national educational objectives, as well as those that arise out of the needs for sustainable development of increasingly interconnected and interdependent world, out of the need for resolving global problems of mankind (Akhmetova, 2007). It is through increased cooperation at educational institutions in the implementation of large international projects when the necessary interaction of the national educational structures is achieved, and it is this that distinguishes the internationalization from integration.

However, among the factors impeding the improvement of the competitiveness of the Russian education services market under the conditions of the international educational integration, the following can be described: belated Russia's joining the Bologna process jeopardizes its competitive positions in the international market of educational services (Krasnova, 2002); insufficient time for adapting the educational environment of Russia to the European conditions hinders the development of effective mechanisms to enhance its competitiveness; heterogeneity of Russian universities' entering into the competitive environment of the educational market entails a crisis in their functioning; lack of a deliberate strategy for managing the market of educational services in Russia weakens the effectiveness in the struggle for its educational space; inefficient legislation is inconsistent with the goals of education development in a market economy; the educational content does not sufficiently correspond to the goal-oriented, targeted education for future specialists.

\section{Conclusion}

The proposed research and methodological practices in the article for improving the competitiveness of the Russian education services market under the conditions of the international educational integration at the federal (legal and regulatory, organizational and pedagogical, organizational and methodological program), regional (legal and regulatory, organizational and administrative, organizational and methodological, and socially-pedagogical program) and university levels (legal and regulatory, organizational and administrative, socially-pedagogical, learning and teaching, and information-technology program) may be useful for international departments of higher education institutions in order to optimize the processes of Russian universities entering into the international educational space.

\section{References}

Avraamova, Y. M., Aleksandrova, O. A., \& Loginov, D. M. (2004). Modern higher education and prospects of upward mobility. Social studies and the present, 6, 55.

Akhmetova, D. (2007). Paradoxes of distance learning. Higher education in Russia, 3, 57-62.

Baydenko, V. I. (2009). Bologna transformation: problems and contradictions. Higher education in Russia, 11, 28-29.

Batyukova, Z. I. (2005). The role of international research in the development of pedagogical knowledge (pp. 209-224). Moscow: ITIP.

Balakireva, E. A. (2009). The Bologna process in higher education in Russia and abroad. In International scientific-practical conference correspondence. Ulyanovsk.

Colin, K. (2002). Information Society, globalization and humanitarian revolution. Alma Mater, 8, 3-9.

Evreinov, E. V. (2002). Global education system. The world of education-Education in the world, 4, 88-101.

Fedotov, N. N. (2003). Globalization and Education. Philosophical Sciences, 4, 5-24.

Fayzullina, A. R. (2007). Immigration policy in modern Russia (federal and regional aspects) (Thesis for the degree of Candidate of Political Science. Ufa: Bashkir State University).

Fayzullina, A. R., \& Mukhametzyanova-Duggal, R. M. (2015). Multi-Confessional Societies in Russia and India: Models of Relations between the State and Religious Associations. Review of European Studies, 7(1), 12-17.

Gitman, M., Gitman, E., \& Stolbova, B. (2006). Dual education program: International experience and Russian prospects. Aima mater, 8, 36.

Henvi, R. (1994). Attainable Global Perspective (p. 84). Ryazan. 
Huseynov, L. A. (2005). Socio-cultural development of education systems: A regional perspective. Higher education today, 9, 54 .

Klimanovich, O. (2001). Conceptual and terminological aspect of the problem of internationalization of higher education. Alma Mater: Bulletin of higher education, 1, 10-13.

Krasnova, G. (2002). The Institute of Distance Education. Higher education in Russia, 5, 123-126.

Levina, E. Y., Saglam, F. A., Skorobogatova, A. I., Shaikhlislamov, A. Kh., Sagitova, V. R., \& Fayzullina, A. R. (2015). Quality Control Optimization of University Students Training. Asian Social Science, 11(2), 296-300.

Liferov, A. P., \& Kolker, Y. M. (1995). Global Education and the problems of the modern school (pp. 3-7). Ryazan.

Liferov, A. P., \& Stepanov, N. A. (1997). Education of the future: Global challenges local solutions (p. 49). Moscow.

Lukichev, G. A. (2003). The development of education in the member states of the Bologna process. Higher education today, 8, 34-37.

Masalimova, A. R. (2012). Formation and development of the research competence of technical specialists in the process of intra-training. Kazan pedagogical journal, 3(93), 127-132.

Megrat, A. P. (2001). Globalization and its impact on higher education on a global scale. Higher Education in Europe, $X X V I, 1$.

Merzon, E. E., Fayzullina, A. R., Ibatullin, R. R., Krylov, D. A., Schepkina, N. K., \& Pavlushkina, T. V. (2015). Organizational and pedagogical conditions of academic mobility development of students at school of higher professional education. Review of European Studies, 7(1), 46-51.

Mrathuzina, G. F., Fayzullina, A. R., \& Saglam, F. A. (2015). Substantive, Methodological and Organizational Discourse in Oriental History Learning at School and University. Review of European Studies, 7(1), 57-62.

Pelikhov, N. V., \& Rodionov, A. V. (2009). Targets of universities. Space economy, 3, 297-299.

Popov, A. I. (2002). Common educational environment-A decisive condition for the training of specialists XXI century. Higher education today, 2, 16-22.

Sadlak, J. (2007). Bologna process: Regional response to global challenges. Higher education today, 10, 16-19.

Sakhieva, R. G., Khairullina, E. R., Khisamiyeva, L. G., Valeyeva, N. S., Masalimova, A. R., \& Zakirova, V. G. (2015). The Syllabus of the Regional Component of Professionally Motivational Education Developed for the Students Specializing in Tourism. Asian Social Science, 11(2), 246-251.

Scott, P. (2000). Globalization and the University. Alma Mater: Bulletin of higher education, 4, 3-8.

Shaidullina, A. R., \& Masalimova, A. R. (2006). Foreign experience of integration of research, teaching and practice of students of higher technical school. Kazan Pedagogical Journal, 5(47), 54-61.

Yermolyeva, E. G. (1994). On the way to the "Common Market of Knowledge". Latin America, 7, 8.

\section{Copyrights}

Copyright for this article is retained by the author(s), with first publication rights granted to the journal.

This is an open-access article distributed under the terms and conditions of the Creative Commons Attribution license (http://creativecommons.org/licenses/by/3.0/). 